\title{
Enhancing Student Achievement in Social Science through Cooperative Learning Method
}

\author{
Ino Budiatman, Arry Patriasurya \\ Department of Elementary Teacher Education \\ Universitas Muhammadiyah Tangerang \\ Tangerang, Indonesia \\ ibudiatman@gmail.com
}

\begin{abstract}
The research is aimed to investigate which technique is the most effective in cooperative learning method: Jigsaw, Numbered Head Together (NHT) and Group Investigation (GI) in increasing students' learning achievement in social science. Three schools were chosen by using cluster random sampling. Each of sample is taught the same materials in social sciences by using different technique for four times. Data analysis shows that there is a significant difference on students' achievement before and after treatment. There is also a significant difference on student achievement using jigsaw and NHT as well as GI. Further analysis shows that GI seems to be higher on students' achievement than jigsaw and NHT as well and they are different significantly. The research concludes that GI technique tend to be most effective to increase student achievement among those three techniques and then is followed by NHT and Jigsaw.
\end{abstract}

Keywords-cooperative learning; jigsaw; NHT; GI; student achievement

\section{INTRODUCTION}

While Indonesia is facing ASEAN Free Trade Agreement (AFTA), there is a growing concern to prepare young generation to be able to widely participate in this chance. It becomes a serious concern for Indonesia HDI is ranked to be number 5 among 9 members of ASEAN countries. As it is widely known, one of HDI determinants is quality of education To increase this educational quality, teachers can conduct the learning process by increasing students' achievement and it is a complicated factor since there are many interrelated factors to be noticed [1].

Bronfenbrenner [2] proposes Bio-ecological Model which one of them emphasizes importance of interactive experiences among learners. In order to increase those experiences, some educational practices and researchers introduce cooperative learning methods that has a significant correlation with students achievement, inter students relation, self-esteem, and general developing knowledge [3]. Furthermore, he argues that the aim of collaborative method is using learner potentials to share with his peers in his group in the class. Consequently, all the group members has a better comprehension about materials they are learning rather than teacher explain it alone [3].

Since introduced for first time, cooperative learning method has attracted educational researchers and practitioners to develop its models. Slavin [3] identifies more than six models using this cooperative learning methods: (a) Student TeamsAchievement Divisions (STAD), (b) Teams-GamesTournaments (TGT), (c) Team Assisted Individualization (TAI), (d) Jigsaw Learning Together Group, (e) Investigation and (f) other learning models. These models have been used broadly in teaching practices. Beside in schools, cooperative learning method is also used in leadership training and, in fact, it can increase leadership competencies. Garcia, Abrego, and Robert [2] find that they who are trained by using jigsaw model shows better leadership. It is a logic one since Dewey argued that

If humans are to learn to live cooperatively, they must experience the living process of cooperation in schools. Life in the classroom should represent the democratic process in microcosm, and the heart of democratic living is cooperation in groups [5].

Since it has another advantage to increase students' social skills, cooperative learning model is useful to apply for children in order to prepare them as a democratic citizen. Therefore, implementing cooperative learning method has a great advantage in preparing the student to learn to live together. Schmuck [5] asserts that one thing that has to be noticed in preparing young generation to a democratic citizenship is to let them learn to handle any problems constructively and creatively. This afore mentioned statement implies that learning through cooperative model has not only advantages to build students cognitive, but also maintain their attitude in facing any differences in social context.

The problems, now, is teaching models in this cooperative learning has many techniques. Besides, as it has been cited before, there are many developed teaching models beyond this cooperative learning. Suprijono [6] identifies some of this teaching models that root to cooperative learning as follows: (a) Jigsaw, (b) Number Heads Together (NHT), (c) Think-PairShare, (d) Team Assisted Individualization, (e) Student Teams Achievement Divisions, (f) Picture and Picture, (g) Problem Solving, (h) Team Games Tournament, (i) Cooperative integrated, (j) Reading and Composition, (k) Learning Cycle, (1) Cooperative Script, (m) Cooperative Make a Match, (n) Group Investigation, and so on.

Slavin [3] states that cooperative learning methods are capable of being used at any grade level and in most school 
subjects. Since it was firstly introduced, cooperative learning methods have attracted researchers and academics intention and in 2009, no less than 1,200 studies related to cooperative learning methods and most of them emphasized the effect of cooperative learning methods on learning outcomes and comparison with other learning methods [7]. Cooperative learning methods, in fact, are not only used in the academic world, but also in leadership training. Those who were trained in the jigsaw cooperative learning technique, one of the cooperative method-based learning techniques, showed a significant increase in the aspects of participant leadership [4].

There are many teaching techniques in this cooperative learning method, therefore, it is necessary to limit into three techniques, namely: (a) jigsaw (JIG); (b) Numbered Head Together (NHT); and (c) Group Investigation (GI). The subject that was to be studied was limited to social science subjects since their answers are various and one can have different perspectives about it. This research try to find out which teaching technique among those three techniques is the most effective one in increasing students' achievement.

Theoretical framework of this research is based on Gillies' [8] conclusion that cooperative learning is different from learning together. The failure that is often found in learning together is diminished by constructing five components of successful cooperative learning to its structure. Firstly, it should create positive interdependence structure that students link together in such a way that one cannot achieve success unless they all do, and they must learn to synchronize their efforts to ensure this occurs. Secondly, the structure and the class should promote interaction and facilitate each other's efforts to complete their tasks in order for the group to achieve its goal. Thirdly, the group has to build individual accountability or one's responsibility in ensuring that he or she completes his or her share of the work while also ensures that others complete theirs. The next, students need to be taught the social skills needed for high quality cooperation and they must be motivated to use them if they are to facilitate learning themselves and others. Furthermore, providing students with feedback on how they use these skills not only helps to create more positive relationships among group members, but it also helps to increase students' achievement. The last, successful cooperative learning depends on group processing. Group processing involves students reflecting on their progress and their working relationships.

Schmuck [5] finds that a meaningful learning is where students try to integrate their new knowledge with the old ones and it is better than to memorize it. One of methods to integrate them is sharing various experiences among the students. Cooperative learning is built on this context. Cooperative learning is a learning method that refer to constructivism that emphasizes building knowledge from experiences and through cooperation learning among various students in a group [9]. In cooperative learning, students learn together cooperatively in a small group and in structured activity where students face each other in a classroom [10].

Cooperative learning can be defined as students working together in a group to get group goals that cannot be obtained through self-employment or competition [11]. Nevertheless,
Adams [10] emphasizes the importance of structuring activities so that the learning process can run more effectively. Through this structured activity the participants learn to share knowledge within their groups and continue to expand in their classrooms.

Well-structured methods such as those found in cooperative learning have a positive influence on the size of learning outcomes compared to other learning practices even though they use innovative curriculum textbooks [3]. The problem, then, is that techniques that can be used to implement cooperative learning methods are very diverse so it needs to be compared to understand which techniques are more effective in improving learning outcomes. To techniques can be described as follows.

\section{A. Jigsaw Technique}

Jigsaw was one of the earliest of the cooperative learning methods. In Jigsaw, each student in a group of five to six members is given unique information on a topic that the whole group is studying. After students read their sections, they meet in "expert groups" with their counterparts from other groups to discuss the information. Next, the students return to their groups and teach their team mates what they have learned. The entire class may take a test for individual grades at the end [12].

The main point of the jigsaw method is that the contents of the lesson to be acquired are divided into as many parts as the number of micro-groups, or as the number of the members in a small group. Then the children engaged in different parts teach each other their own segments. Then the lesson is built up together as a whole, step by step, like a jigsaw puzzle [12].

According to Adams [10], the jigsaw technique cooperative learning method was developed by social psychologist Elliot Aronson in 1971. This technique divides the learning participants with different competencies into groups of 4 to 5 study participants. This group is then divided into "expert" categories. After summarizing the subject matter, they are studying, the expert from each group then deepens the conclusions they have arranged in their respective groups to be explained into their respective groups.

Suprijono [6] asserts that jigsaw learning techniques begins by introducing a chosen topic by writing it on the board and then the teacher captures answers from students to find out which students understand the topic. They were then distributed to each group of 10 people and became experts in the group, while other students were categorized as textual groups. After each group discussed and concluded what they discussed in the group, these experts were then gathered in one group to discuss conclusions that they make in their respective groups. After getting the final conclusion, they go back to their original group to explain the final conclusions they got during discussions with other experts and then presented and reviewed together and the teacher closes the learning session by giving a summary of the material.

\section{B. NHT Technique}

The students in a small group are structured with the aim of influencing the pattern of student interaction. This structure is basically in order to make students can work with each other to 
rely on small groups cooperatively. As its basic principle norm, NHT enable students to learn from each other, work together, and must check that everyone can understand and answer the question. Students are accountable to each other for sharing the ideas, they may also be required to share their partner's ideas to another pair or whole group. Every student must be able to give the group response to the question. Each student within the group has an equal opportunity to share. High degrees of interaction at any one moment all of the students will be actively engaged in purposeful speaking and listening. In the end of process, that number is called, called again by the teacher. This technique makes that not all members of the group called by the teacher.

Like preceding technique, according to Arató and Varga [12] NHT is done by dividing students into small groups that consists of 9-10 students and each group member is given a numbers between 1 to 9 or 10 . After the teacher gives the topic to be studied, each group is, then, given a time to discuss it together. After discussing period, the teacher mentions a number between 1 to 9 or 10 randomly and the student who own the number from each group has to describe the topics and answer the questions given by the teacher or any classmates. When the students cannot answer the questions correctly, other members of his/her group can help.

\section{GI Technique}

GI is one of techniques in the form of cooperative learning for classroom instruction in which students work collaboratively in small groups to examine, experience, and understand their topic of study [13]. GI enable the students to interact in the classroom by positive interdependence and individual responsibility. They should collaborate their skills to discuss many topics with their group.

Arends [14] states that GI was originally designed by Herbert Thelen. More recently, this approach is extended and enhanced by Sharan and his colleagues at Tel Aviv University. GI approach involves students in planning the topics to be studied and how to run the investigation. This requires norms and class structure that is more sophisticated than the approaches in teacher centred.

Steps in implementing GI, according to Arends [14] are: (1) Students choose a specific sub-topics within the field of certain common problems, which are usually explained by the teacher. They, then, are organized into small groups consisting of taskoriented two to six people. The composition of the hetero generous group both academically and ethnically; (2) Students and teachers plan procedures, tasks, and specific learning objective in accordance with sub-sub selected topics; (3) Students implement the plan and learning should involve a variety of activities and skills and should lead students to a variety of a sources inside and outside o school. The teacher follows closely the development of each group and offer help when needed; (4) Students analyse and evaluate information obtained and plan for how this information can be summarized by drawing to be displayed or presented to classmates; (5) Some or all groups in the class give an interesting presentation on topics to make each other involved in his work and achieve a broader perspective about a topic; and (6) The students and the teacher evaluate the contribution of the whole work in each group. The evaluation included individual and group assessment or both of them.

\section{METHOD}

The aim of this research is to find out the effectiveness of Jigsaw, NHT and GI techniques that belong to cooperative learning methods on student achievement in learning social science by using experiment analysis. Population is Government Elementary schools in Tangerang district. Sample is three schools that is taken by using cluster random sampling. Each school is represented by its grade 5. They are given treatment for four times by using different technique. The first school with 39 students is taught by using Jigsaw technique, the second with 31 students by NHT, and the last with 33 students by GI. Lesson materials were selected according to school curriculum that is stated in official 2013 curriculum.

Treatment for the first sample is conducted by dividing the students into group that consists of 4-5 students homogenously and one or two of them is appointed as an expert(s). They are given a puzzle to be arranged, discuss the theme of the picture they have arranged together and write a description in their group before presenting the result in front of the class by one of group members. The second sample is also divided into groups contain 4-5 homogenous students and one of them is appointed as an expert. Each member is given number. They also are given a puzzle to arrange together in their group. After finishing the puzzle, they have to discuss the picture and make a description together. In the end of the class, teacher state a number between 1 and 4 . The number students that is stated in each group has to present their group works in front of the class. Just like preceding procedure, the last sample group is also divided into groups contain 4-5 homogenous students and one of them is appointed as an expert.

For the third sample, the students are divided into 4 or 5 group of students. All group then decide which subtopic they have to learn, how the procedure and steps to be followed. After discussing for a period of time, each group is given time to present the result of their discussion. In the end of class, the teacher makes conclusion by stating the contribution of the groups in forming the knowledge they have obtained.

In the end of treatment, all samples were tested by using an objective test that has been examined for its validity and reliability. Its validity is measured by using $r$ product moment that produces 20 valid item. Its reliability coefficient is 0,84 by using KR 20 technique. The test items are used in conducting pre-test and post-test.

\section{RESULTS AND DISCUSSION}

By using statistical software, students' achievement before given treatment with those three techniques can be seen as follows. The $\mathrm{p}$ value $>0,05$ that means there is no significant difference among the classes before they are taught by using techniques that belong to cooperative learning methods.

After the classes are taught by using different techniques student achievement tend to be higher. The statistical test mentions that $p$ value $<0,05$ that means there is a significant different for this achievement after treating them in different 
way. In order to know the differences, analysis, then, is continued by using Turkey and the result can be drawn below.

TABLE I. COMPARISON OF THE THREE TECHNIQUES Tukey HSD

\begin{tabular}{l|r|r|r} 
& & \multicolumn{2}{|c}{ Subset for alpha $=0.05$} \\
Metode Collaborative & N & \multicolumn{1}{c}{1} & \multicolumn{1}{c}{2} \\
\hline JIG & 39 & 15,9487 & \\
\hline NHT & 30 & 16,4667 & \\
\hline IG & 33 & & 17,6364 \\
\hline Sig. & &, 271 & 1,000 \\
\hline
\end{tabular}

The table above describes that there is no significant different between Jigsaw and NHT technique in increasing student achievement in learning social science, but both of them differs significantly with GI technique. Based on their average score in student achievement, it can be inferred that the most effective technique in increasing elementary student achievement in learning social science beyond cooperative method is GI, then is followed by NHT and Jigsaw. Through those analyses it can be understood that Jigsaw and NHT technique is not different significantly and they can be used interchangeable. Meanwhile, GI technique is different with those techniques in increasing student achievement in learning social science for elementary schools.

Based on above finding, among those three techniques that are examined in this study, GI technique tend to be the most effective one in increasing student achievement. One reason for this fact is grounded by student involvement in deciding the subtopic that they want to learn. The techniques increase students' self-esteem and self confidence in learning topics they are discussing. It is not surprising because one of advantages in using cooperative method is for this reason. Students are both pupil and human that own its unique willingness. When the teacher can accommodate them, students spirit to learn will increase. If they fail to understand the topic, they can ask their friends. For Indonesian students, sometimes they worry or are ashamed to ask the teacher if they cannot understand material they are learning. Therefore, they can ask friends to help. Not only that, before expressing their ideas, they can also listen to other ideas and construct another new idea.

As it is stated by Dewey that is cited by Schmuck [5] "Life in the classroom should represent the democratic process in microcosm, and the heart of democratic living is cooperation in groups". Cooperation in this context is not for the students alone, but also for student and teacher relation. In this case, the teacher is viewed by students as their peers for the teacher involve the students to decide what learning material they are interested in.

As it has been explained before, cooperative learning method has an effect on student achievement. This achievement may be directly affected by increasing cognitive aspect, but it is not impossible this cognitive aspect is affected by increasing affective aspect, such as self-esteem and self-confidence. Therefore, there should be another study to find out whether these cooperative learning affect directly on cognitive aspect or indirectly through affective one.

\section{CONCLUSION}

Due to preceding analysis, it can be concluded that among those three techniques on cooperative learning method that are tried to study in this experiment, GI is the most effective on in delivery the social study lesson. Meanwhile Jigsaw and NHT techniques are not different significantly in increasing student achievement in learning social science.

\section{ACKNOWLEDGMENT}

I would like to express my special thanks of gratitude to Ministry of Research, Technology, and Higher Education which gave me the golden opportunity to do this wonderful project on the topic "Enhancing Students Achievement in Social Science Through Cooperative Learning Method: Study on Official Elementary School in Tangerang District" which also helped me in conducting the research project by preparing financial support. Secondly, I would also like to thank all school principals and teachers who gave me a great chance to conduct the study at their schools and a lot of support in finalizing this project within the limited time frame.

\section{REFERENCES}

[1] UNDP, Human Development Indices and Indicators. 2018 Statistical Update.

[2] U. Bronfenbrenner, "Beyond the deficit model in child and family policy" Teachers College Record, Vol 81(1), 1979, 95-104.

[3] R. E. Slavin, Cooperative learning. Cooperative Learning: Student Teams. What Research Says to the Teacher. Washington, D.C: National Education Association, 2013.

[4] A. Garcia, J. Abrego, and R. Robert "Using the Jigsaw Method for Meaningful Learning to Enhance Learning and Retention in an Educational Leadership Graduate School Course" Global Journal of Human-Social Science: G Linguistics \& Education Volume 17 Issue 5 Version 1.0, 2017. pp 1 - 15

[5] R. Schmuck, "Learning to Cooperate, Cooperating to Learn Basic Concepts" in Learning to Cooperate, Cooperating to Learn Basic Concepts, Robert Slavin et al, eds. New York: Springer Science Business Media, 1985, pp. $1-4$.

[6] A. Suprijono, Cooperative Learning: Teori dan Aplikasi Paikem. Yogyakarta: Pustaka Pelajar, 2015

[7] D.W. Johnson and R.T Johnson, An Educational Psychology Success Story- Social Interdependence Theory and Cooperative Learning. Educational Researcher, 2009, 38, (5), 365-377

[8] R. M. Gillies, Cooperative Learning: Review of Research and Practice, Australian Journal of Teacher Education, 2016 41(3), pp 39 - 54

[9] N. Supriana, et al, Pendidikan IPS (Social Science Esucation). Bandung: UPI Press, 2010

[10] F. H. Adams, Using Jigsaw Technique As An Effective Way Of Promoting Cooperative Learning Among Primary Six Pupils In Fijai, International Journal Of Education And Practice, 2013, 1(6):64-74

[11] D.W. Johnson, R.T. Johnson and E.J. Holubec, Circles of learning: Cooperation in the classroom. Edina, MN: Interaction Book Company, 1986.

[12] F. Arató and A. Varga, A Handbook for learning together - an introduction to co-operative learning, Róbert Marcz and Berta Bakony (trans.) Pecs: University of Pécs, Faculty of Humanities, Institute of Education Sciences, 2015

[13] Y. Sharan and S. Sharan, Expanding Cooperative Learning Through Group Investigation. New York and London: Teachers Collages, Columbia University, 1992.

[14] R. I. Arends, Learning to Teach: Seventh Edition. New York: McGraw Hills Companies, 2008. 